\title{
Oxidation and Reduction of Liquid SnPb (60/40) under Ambient and Vacuum Conditions
}

Kuhmann, Jochen Friedrich; Maly, K.; Preuss, A.; Adolphi, B.; Wirth, T.; Oesterle, W.; Fanciulli, M.; Weyer, G.

Published in:

Journal of The Electrochemical Society

Link to article, DOI:

$10.1149 / 1.1838608$

Publication date:

1998

Document Version

Publisher's PDF, also known as Version of record

Link back to DTU Orbit

Citation (APA):

Kuhmann, J. F., Maly, K., Preuss, A., Adolphi, B., Wirth, T., Oesterle, W., Fanciulli, M., \& Weyer, G. (1998). Oxidation and Reduction of Liquid SnPb (60/40) under Ambient and Vacuum Conditions. Journal of The Electrochemical Society, 145(6), 2138-2142. https://doi.org/10.1149/1.1838608

\section{General rights}

Copyright and moral rights for the publications made accessible in the public portal are retained by the authors and/or other copyright owners and it is a condition of accessing publications that users recognise and abide by the legal requirements associated with these rights.

- Users may download and print one copy of any publication from the public portal for the purpose of private study or research.

- You may not further distribute the material or use it for any profit-making activity or commercial gain

- You may freely distribute the URL identifying the publication in the public portal 


\title{
Oxidation and Reduction of Liquid $\mathrm{SnPb}(60 / 40)$ under Ambient and Vacuum Conditions
}

\author{
J. F. Kuhmann, ${ }^{a}$ K. Maly, ${ }^{b}$ A. Preu $\beta,{ }^{c}$ B. Adolphi, ${ }^{c} K$. Drescher, ${ }^{*, c} T$. Wirth, ${ }^{d}$ W. Oesterle, ${ }^{d}$ M. Fanciulli, \\ and G. Weyer
}

${ }^{a}$ Mikroelektronik Centret, Denmark Technical University, DK-2400 Lyngby, Denmark

${ }^{b}$ Heinrich-Hertz-Institut Berlin, Germany

'Institut für Halbleiter und Mikrosystemtechnik, Technische Universität Dierden Dresden, Germany,

${ }^{d}$ Bundesanstalt für Materialforschung, Berlin, Germany

'University of Aarhus, Denmark

\begin{abstract}
One of the most straightforward approaches to fluxless solder bonding is using vacuum conditions to prevent further oxidation and, where needed, to reduce solder oxides by the use of molecular hydrogen $\left(\mathrm{H}_{2}\right) .{ }^{1-3}$ This study on oxidation and reduction of solder oxides on $\mathrm{SnPb}(60 / 40)$ is aimed to provide a better understanding for fluxless solder bonding applications under controlled atmospheric conditions. By means of scanning Auger spectroscopy it is shown, that growth of oxide films on metallic $\mathrm{SnPb}$ above the eutectic temperature can be significantly reduced by decreasing the $\mathrm{O}_{2}$ partial pressure up to $\sim 10^{-5} \mathrm{~Pa}$. The native oxide, which was left on top of one part of the samples, prevented a further scale growth even during heating at temperatures above the melting point. The native oxide consists of $\mathrm{SnO}_{2}$, which has most likely an amorphous structure, whereas the oxide, grown at 200 and $250^{\circ} \mathrm{C}$ is crystalline SnO. For sample preparation, the reduction of the native oxide on eutectic $\mathrm{SnPb}$ was carried out successfully using low temperature $\left(250^{\circ} \mathrm{C}\right)$ and short heating cycles $(2 \mathrm{~min})$. The effectiveness of $\mathrm{H}_{2}$ to reduce $\mathrm{SnO}_{2}$ at typical soldering parameters $\left(240^{\circ} \mathrm{C},<2 \mathrm{~min}\right)$ was furthermore proven by in situ Auger electron spectroscopy.
\end{abstract}

\section{Introduction}

Oxide on solder surfaces leads to poor wetting and bad adhesion of the assembled parts. In general, fluxes are used to take away the oxides and surface contaminations and protect the solder from reoxidation.

For the assembly of photonic devices and micromachined systems, however, fluxes should be avoided. In photonics fluxes can degrade the unprotected devices or attenuate the optical signal. In the case of micromechanical devices, fluxes can clog nozzles and orifices or destroy sensitive membranes. In microelectronics, fluxless soldering is under investigation for economic reasons and for reliability improvements.

The starting point for soldering operations is a solder surface covered by its native oxide. The native oxide on $\mathrm{SnPb}(60 / 40)$ has a thickness of $\sim 3 \mathrm{~nm}$, which remains unaffected even after extended shelf storage of 3 months; even after 1 year, the oxide will only insignificantly grow.

The oxide growth on $\mathrm{SnPb}(60 / 40)$ at temperatures below $120^{\circ} \mathrm{C}$ follows a logarithmic law, whereas at higher temperatures, parabolic growth kinetics can be observed..$^{5,6}$ At temperatures of 160 and $170^{\circ} \mathrm{C}$, an increase in thickness of up to approximately $20 \mathrm{~nm}$ after 80 days has been reported. ${ }^{7}$ The oxide layers on $\mathrm{SnPb}(60 / 40)$ were found to contain both tin and lead, with tin being oxidized preferentially.

The oxide on solid and liquid tin was reported to consist of both stannous oxide and stannic oxide $\left(\mathrm{SnO} \text { and } \mathrm{SnO}_{2}\right)^{8,9}$ Britton et al. ${ }^{10,11}$ examined oxide films grown on Sn at temperatures below $180^{\circ} \mathrm{C}$ using transmission electron microscopy (TEM). The authors did not observe any electron diffraction pattern whereas Boggs ${ }^{12}$ identified the oxide, grown on $\mathrm{Sn}$ at $75^{\circ} \mathrm{C}$ as crystalline $\alpha-\mathrm{SnO}$. The author pointed out that the samples needed to be heated long enough $(>800 \mathrm{~h})$ to obtain enough crystalline material.

The oxidation of liquid $\mathrm{SnPb}(60 / 40)$ at different temperatures has been investigated by different authors. ${ }^{13-15}$ All oxidations were carried out under ambient, the starting point of oxidation being fresh, metallic solder surfaces. In all experiments, a parabolic growth of the oxide layers has been observed, the actual thickness depending very much on the sample preparation and the employed analysis technique (Fig. 1). Electron diffraction of the oxidized samples identified $\mathrm{SnO}$ and $\mathrm{SnO}$, and also $\mathrm{PbO}$.

* Electrochemical Society Active Member.
In addition to that, a considerable amount of publications exist that focus on surface tension measurements of Sn and the influence of oxidation on the surface tension. In Ref. 16, a kinetic and fluodynamic model is described which gives, in addition to thermodynamic models, the influence of gas flow parameters and geometry on the oxidation of Sn. The model nevertheless excludes high vacuum conditions employed in this study. The influence of oxidation on surface tension has been investigated in Ref. 17 Here, a distinct drop in surface tension at temperatures between 300 and $500^{\circ} \mathrm{C}$ was observed by increasing the $\mathrm{O}_{2}$ partial pressure from $10^{-16}$ to $10^{-6} \mathrm{~Pa}$. To obtain these pressures the authors used a helium/hydrogen mixture. Data obtained in high vacuum $\left(5 \times 10^{-6}\right.$ to $\left.1 \times 10^{-7} \mathrm{~Pa}\right)$ showed especially in the range of 250 to $400^{\circ} \mathrm{C}$ extensive scattering. Another investigation on surface tension of $\mathrm{Sn}^{18}$ found that at an $\mathrm{O}_{2}$ partial pressure of $4 \times 10^{-6} \mathrm{~Pa}$ at $290^{\circ} \mathrm{C}$, no oxygen peak was detected during Auger electron spectroscopy (AES) on the surface of the molten Sn droplet for $2 \mathrm{~h}$.

$\mathrm{SnO}_{2}$ is the thermodynamically most stable oxide below $250^{\circ} \mathrm{C}$

$$
\begin{aligned}
\mathrm{Sn}+\mathrm{O}_{2} & \rightleftarrows \mathrm{SnO}_{2} \\
p_{\mathrm{O}_{2}}\left(250^{\circ} \mathrm{C}\right) & =10^{-43} \mathrm{~Pa}
\end{aligned}
$$

Equation 1 describes the oxidation of $\mathrm{Sn}$ to stannic oxide $\left(\mathrm{SnO}_{2}\right)$. For equilibrium conditions $(\Delta G=0)$, the reaction

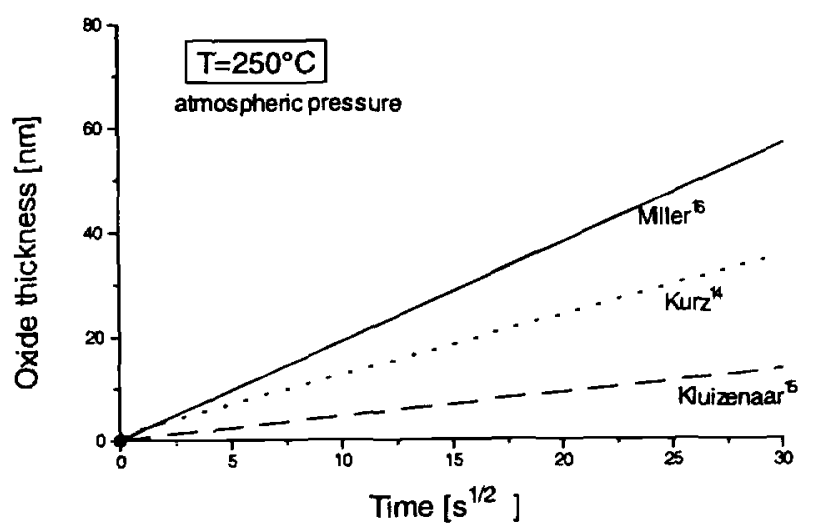

Fig. 1. Fitted data of parabolic oxide growth on $\mathrm{SnPb}(60 / 40)$ at $250^{\circ} \mathrm{C}$ in ambient. 
Table I. Thermochemical data on $\mathrm{Sn}$ and $\mathrm{Pb}$ oxides and on $\mathrm{H}_{2} / \mathrm{H}_{2} \mathrm{O}$ ratios which determine the $\mathrm{O}_{2}$ equilibrium partial pressures for the oxidation at a given temperature. ${ }^{24}$

\begin{tabular}{|c|c|c|c|c|c|c|c|c|c|c|c|c|}
\hline \multirow[t]{2}{*}{$T\left({ }^{\circ} \mathrm{C}\right)$} & \multicolumn{4}{|c|}{$G^{0}\left(\mathrm{~J} / \mathrm{mol} 10^{5}\right)$} & \multicolumn{4}{|c|}{$p_{\mathrm{O}_{2} \mathrm{GG}}(\mathrm{Pa})$} & \multicolumn{4}{|c|}{$p_{\mathrm{H}_{2}} / p_{\mathrm{H}_{2} \mathrm{O}}$} \\
\hline & $\mathrm{SnO}$ & $\mathrm{SnO}_{2}$ & $\mathrm{PbO}$ & $\mathrm{PbO}_{2}$ & $\mathrm{SnO}$ & $\mathrm{SnO}_{2}$ & $\mathrm{PbO}$ & $\overline{\mathrm{PbO}_{2}}$ & $\mathrm{SnO}$ & $\mathrm{SnO}_{2}$ & $\mathrm{PbO}$ & $\overline{\mathrm{PbO}_{2}}$ \\
\hline 150 & -4.90 & -4.93 & -3.54 & -2 & $2 \cdot 10^{-56}$ & $1 \cdot 10^{-56}$ & $2 \cdot 10^{-39}$ & $2 \cdot 10^{-20}$ & 590 & 840 & $2 \cdot 10^{-6}$ & $7 \cdot 10^{-16}$ \\
\hline 200 & -4.82 & -4.83 & -3.44 & -1.91 & $7 \cdot 10^{-49}$ & $4 \cdot 10^{-49}$ & $1 \cdot 10^{-33}$ & $8 \cdot 10^{-17}$ & 170 & 210 & $5 \cdot 10^{-6}$ & $1 \cdot 10^{-14}$ \\
\hline 250 & -4.74 & -4.74 & -3.34 & -1.81 & $4 \cdot 10^{-43}$ & $4 \cdot 10^{-43}$ & $2 \cdot 10^{-28}$ & $8 \cdot 10^{-14}$ & 82 & 80 & $8 \cdot 10^{-6}$ & $2 \cdot 10^{-13}$ \\
\hline 300 & -4.64 & -4.63 & -3.24 & -1.72 & $4 \cdot 10^{-38}$ & $5 \cdot 10^{-38}$ & $4 \cdot 10^{-24}$ & $2 \cdot 10^{-11}$ & 35 & 31 & $1 \cdot 10^{-5}$ & $1 \cdot 10^{-12}$ \\
\hline $350^{\mathrm{a}}$ & -4.54 & -4.52 & -3.14 & & $7 \cdot 10^{-34}$ & $1 \cdot 10^{-33}$ & $2 \cdot 10^{-2 !}$ & & 16 & 13 & $2 \cdot 10^{-5}$ & \\
\hline
\end{tabular}

a For $\mathrm{PbO}_{2}$ data only, available for temperatures up to $314^{\circ} \mathrm{C}$.

is determined by the change in the Gibbs free energy $\Delta G^{0}$ at a given temperature, and the $\mathrm{O}_{2}$ partial pressure, $p_{\mathrm{O}_{2}}$, normalized by the $\mathrm{O}_{2}$ partial pressure under standard conditions, $p_{\mathrm{O}_{2}}^{0}$, as described in Eq. 2. The values for $\Delta G^{0}$ and for $p_{\mathrm{O}_{2}}$ can be taken from Table I. For values above $p_{\mathrm{O}_{2}}$, oxidation of $\mathrm{Sn}$ will still occur. For values below $p_{\mathrm{O}_{2}}$, which is, e.g., $10^{-43} \mathrm{~Pa}$ at $250^{\circ} \mathrm{C}$, the oxide will decompose. In order to achieve values in that order of magnitude the reaction of $\mathrm{H}_{2}$ with $\mathrm{O}_{2}$

$$
\begin{gathered}
2 \mathrm{H}_{2} \mathrm{O}+\mathrm{O}_{2} \rightleftarrows 2 \mathrm{H}_{2} \mathrm{O} \\
p_{\mathrm{O}_{2}}=\frac{p\left(\mathrm{H}_{2} \mathrm{O}\right)^{2}}{p\left(\mathrm{H}_{2}\right)} \exp \frac{\Delta G^{0}}{R T}
\end{gathered}
$$

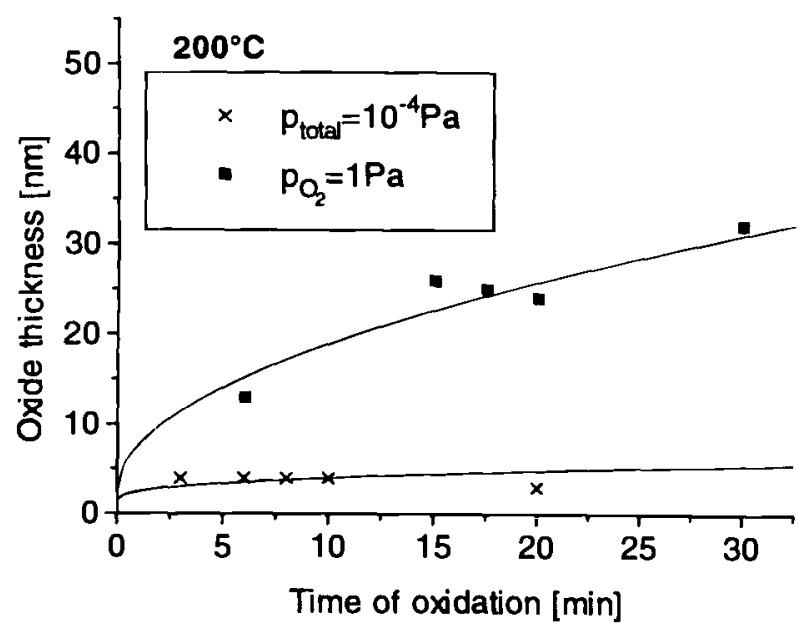

Fig. 2. Scale growth on liquid $\mathrm{SnPb}(60 / 40)$ at different pressures at $200^{\circ} \mathrm{C}$.

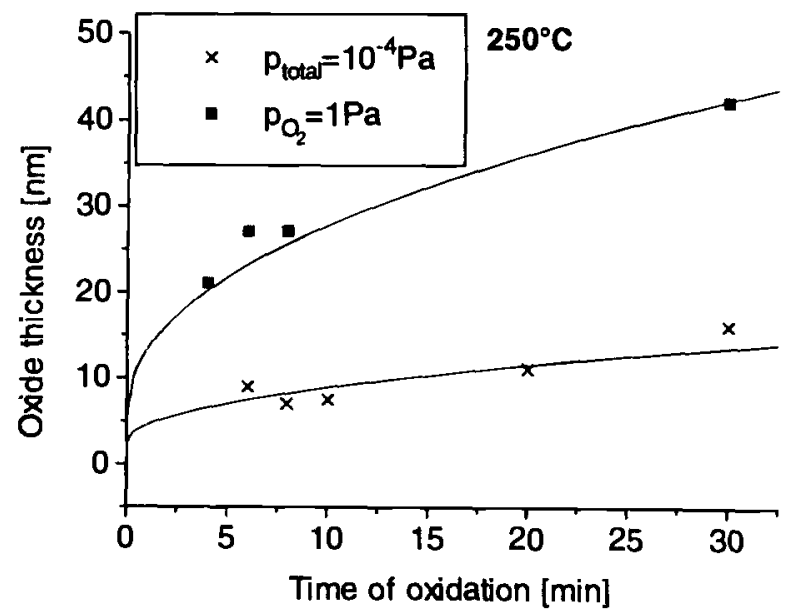

Fig. 3. Scale growth on liquid $\mathrm{SnPb}(60 / 40)$ af different pressures of $250^{\circ} \mathrm{C}$. can be utilized (Eq. 3). At a given temperature, this reaction determines the $\mathrm{O}_{2}$ partial pressure according to Eq. 4 . The values for this reaction which result in an $\mathrm{O}_{2}$ partial pressure of $10^{-43} \mathrm{~Pa}$ are given in terms of the $p_{\mathrm{H}_{2}} / p_{\mathrm{H}_{2} \mathrm{O}}$ ratios in Table I.

$\mathrm{H}_{2}$ has been successfully used in the surface tension studies on $\mathrm{Sn}$ which were mentioned above to obtain oxide free surfaces. Nevertheless, the effectiveness of $\mathrm{H}_{2}$ to reduce $\mathrm{Sn}$ oxides at typical soldering temperatures is misconceived in some technical publications. ${ }^{19-21}$

This might partly be due to one study published in Ref. 22 on the reduction kinetics of some metal oxides. By means of differential thermal analysis (DTA), it was found that the decomposition of the stannic oxide powder under $\mathrm{H}_{2}$ atmosphere only started above $\left(400^{\circ} \mathrm{C}\right)$. For the reduc-

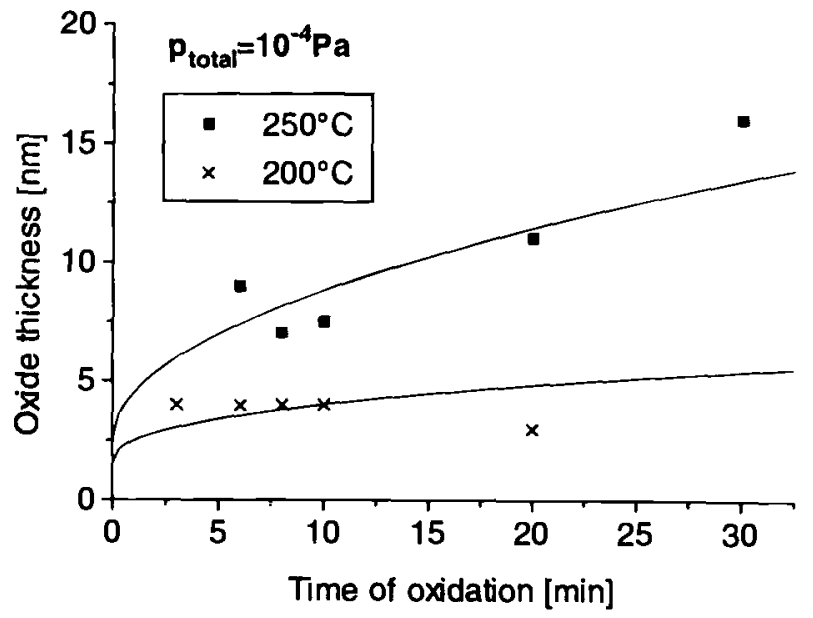

Fig. 4. Scale growth on liquid $\mathrm{SnPb}(60 / 40)$ at $10^{-4} \mathrm{~Pa}$ at 200 and $250^{\circ} \mathrm{C}$.

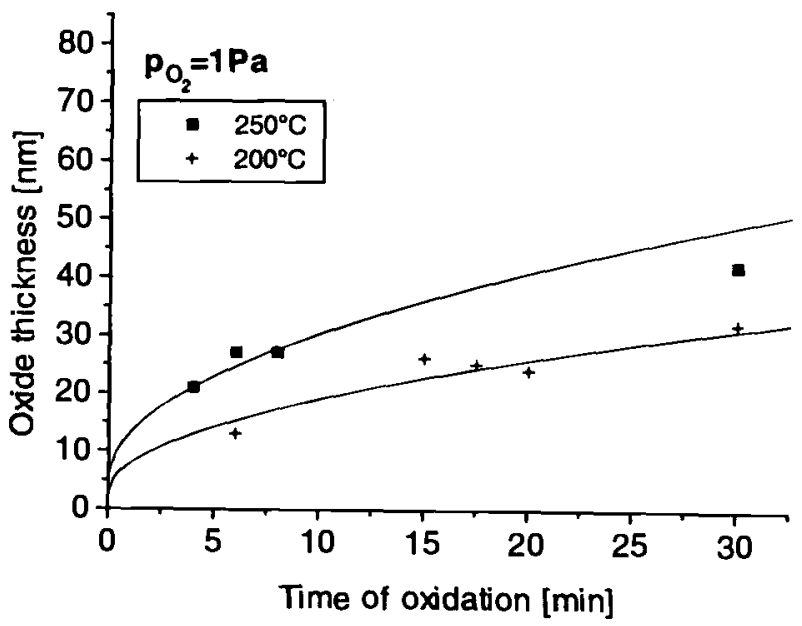

Fig. 5. Scale growth on liquid $\mathrm{SnPb}(60 / 40)$ af $1 \mathrm{~Pa} \mathrm{O}_{2}$ pressure af 200 and $250^{\circ} \mathrm{C}$ 
Table II. Sample preparation.

\begin{tabular}{|c|c|c|c|c|}
\hline \multirow{2}{*}{$\begin{array}{l}\text { Starting point } \\
\text { Temperature }\end{array}$} & \multicolumn{2}{|c|}{$\begin{array}{c}\text { Solder, covered by native } \\
\text { oxide }\end{array}$} & \multicolumn{2}{|c|}{ Fresh solder ${ }^{\mathbb{Z}}$} \\
\hline & $200^{\circ} \mathrm{C}$ & $250^{\circ} \mathrm{C}$ & $200^{\circ} \mathrm{C}$ & $250^{\circ} \mathrm{C}$ \\
\hline $\begin{array}{l}\text { Atmospheric pressure } \\
p_{\text {total. }}=10^{-4} \mathrm{~Pa} \\
p_{\mathrm{O}_{2}}=1 \mathrm{~Pa}\end{array}$ & $\begin{array}{c}5 / 10 / 20 \\
3 / 5 / 10 / 20\end{array}$ & $\begin{array}{l}6 / 10 / 15 / 20 / 30 \\
6 / 10 / 15 / 20 / 30\end{array}$ & $\begin{array}{c}3 / 6 / 8 / 10 / 20 \\
6 / 15 / 17,5 / 20 / 30\end{array}$ & $\begin{array}{c}6 / 8 / 10 / 20 / 30 \\
4 / 6 / 8 / 10 / 20 / 30\end{array}$ \\
\hline
\end{tabular}

${ }^{a}$ Fresh solder surfaces were obtained by reduction of the oxide with $\mathrm{H}_{2}$ at $250^{\circ} \mathrm{C}$ for $2 \mathrm{~min}$.

tion of $\mathrm{PbO}$ by $\mathrm{H}_{2}$, the temperature needed was reported to be $319^{\circ} \mathrm{C}$.

\section{Experimental and Results}

Oxidation kinetics.- The investigation of oxide growth on the heat-treated samples was carried out by scanning Auger measurement (SAM). The energies of the $\mathrm{Ar}^{+}$beam and electron beam were 1 and $3 \mathrm{keV}$, respectively. The diameter of the electron beam was $500 \mathrm{~nm}$, the scanned area was approximately $100 \times 100 \mu \mathrm{m}$. For the determination of sputter rates, $\mathrm{SnO}_{2}$ and $\mathrm{PbO}$ layers of known thickness were sputtered. The average of the measured sputter rates $(25 \mathrm{~nm} / \mathrm{min})$ was used to obtain the oxide thickness from sputter profiles. Sensitivity factors were experimentally determined to correct for sputter and matrix effects and to obtain the unbiased concentration values.

The $\mathrm{SnPb}(60 / 40)$ solder was coevaporated on metallized (Ti/Pt as adhesion and wetable metal, respectively) Si substrates using high purity materials. After evaporation, the samples were molten in an inert organic medium to homogenize. After that, the samples were cleaned and heattreated under different levels of $\mathrm{O}_{2}$ partial pressures. For the oxidation a vacuum chamber with glass plates on top and bottom was used. A focused IR radiation source was used to heat the samples. This configuration allowed rapid heating $(\leq 30 \mathrm{~K} / \mathrm{s})$ and cooling rates, the samples being heated solely by absorption of light. This configuration also provided stable vacuum conditions during the heattreatment, since heating of the chamber walls was avoided. The samples were treated at 200 and $250^{\circ} \mathrm{C}$ in ambient and under vacuum conditions. One part of the samples was treated with the native oxide layer as a starting point, in the rest of the samples, the native oxide layer was reduced by $\mathrm{H}_{2}$ prior to the oxidation.

The native oxide was measured for samples having been stored 3 days and 3 months at $R T$ in ambient. Regardless of storage duration for both oxide layers, a thickness of $\sim 3 \mathrm{~nm}$ was measured. Figure 6 gives a surface spectrum of the
Fig. 6. AES spectrum before sputtering (survey).

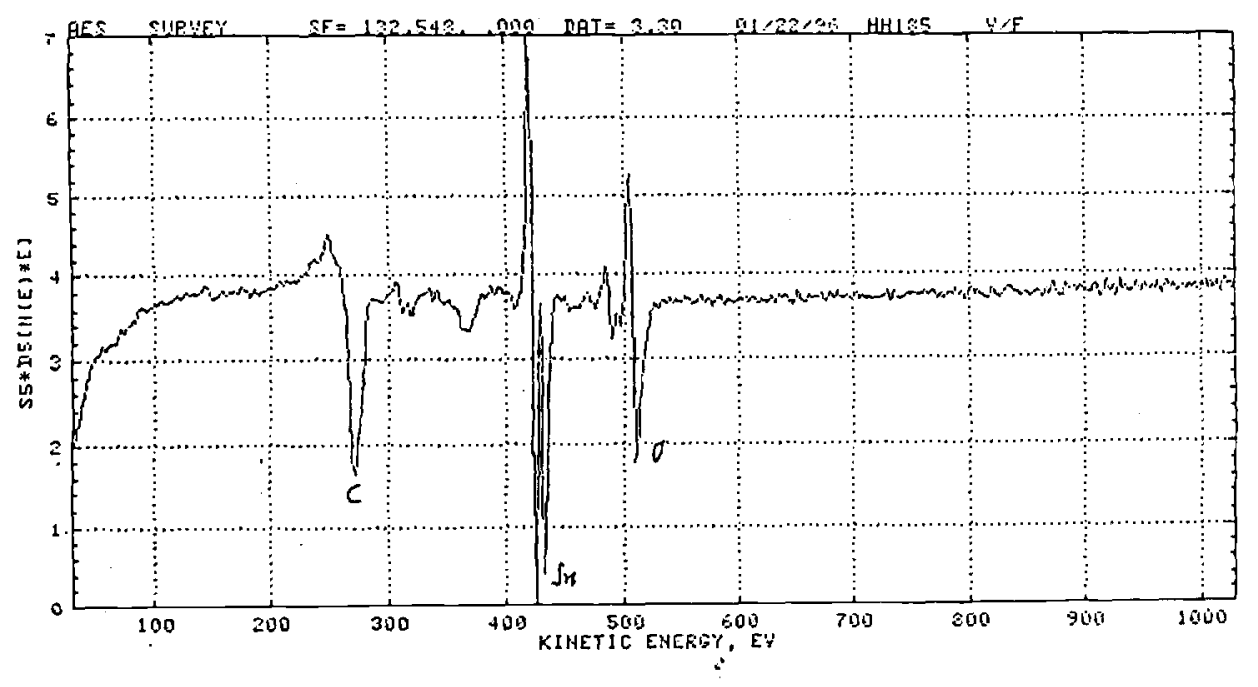

Fig. 7. AES spectrum after spultering.

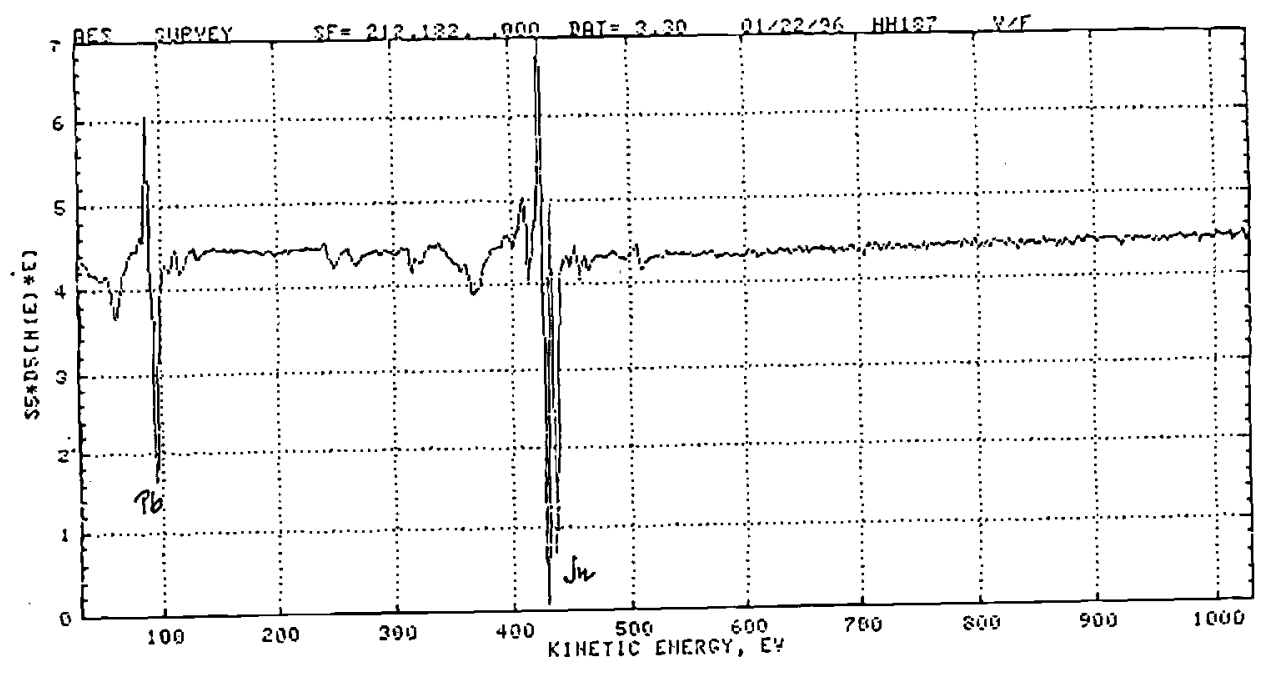




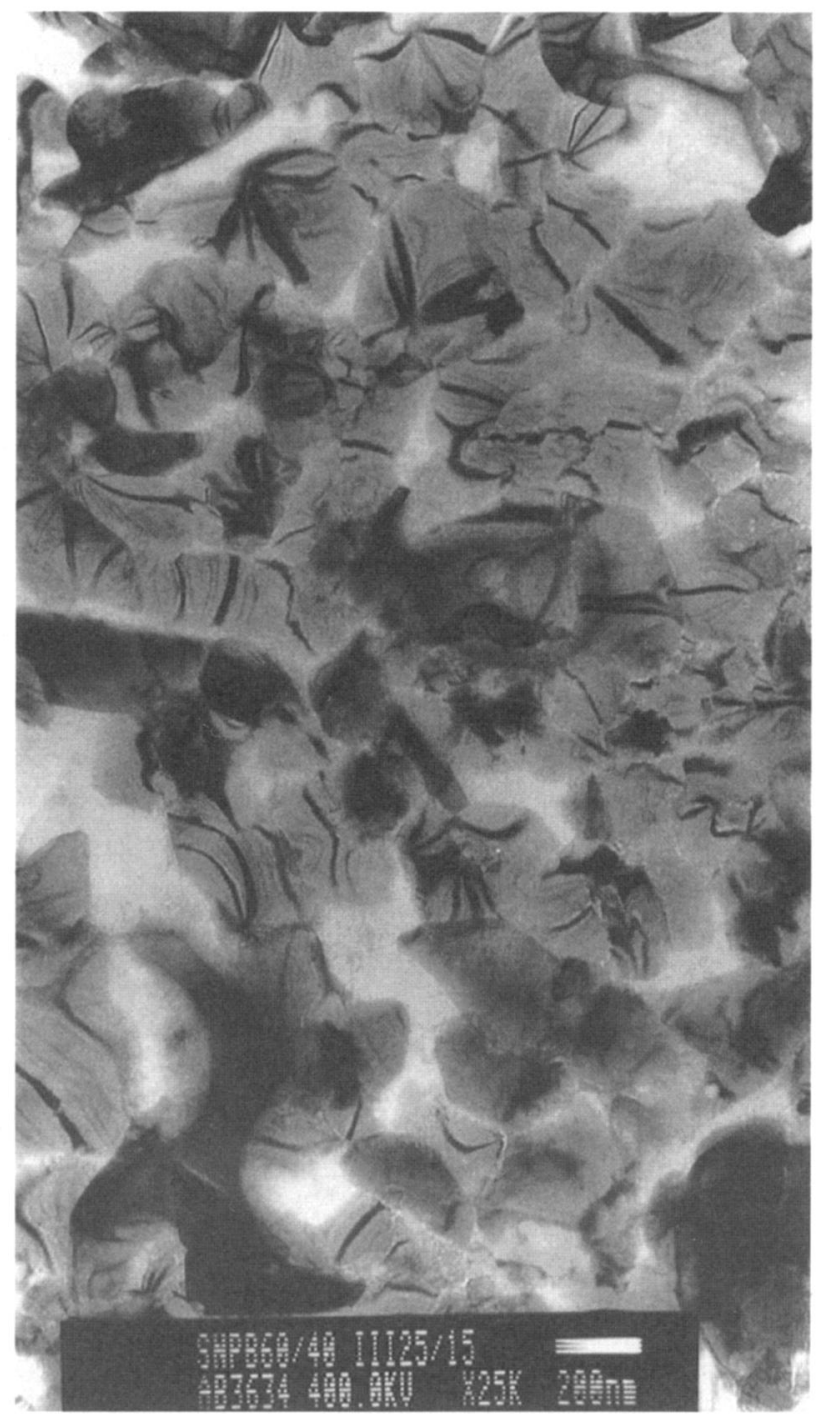

Fig. 8. TEM picture of $\mathrm{SnO}$ crystallites, formed on the metallic solder at $250^{\circ} \mathrm{C}$.

native oxide layers: Besides typical surface contaminants like $\mathrm{C}$ and in some cases also small amounts of $\mathrm{S}$ and $\mathrm{Cl}$ the spectrum only consisted of $\mathrm{Sn}$ and O. Figure 7 shows the spectrum after the oxide has been sputtered. After characterization of the native oxide, the samples were heat-treated in different atmospheres according to Table II.

The samples with the native oxide as starting point of the oxidation exhibited, after treatment in high vacuum and even in ambient at temperatures of 200 and $250^{\circ} \mathrm{C}$, no significant increase in oxide thickness. Only one sample, treated at $250^{\circ} \mathrm{C}$ in high vacuum $\left(p_{\text {total }}=10^{-4} \mathrm{~Pa}\right)$ for $30 \mathrm{~min}$, had an increased oxide thickness of $7 \mathrm{~nm}$. Two samples treated in ambient at $250^{\circ} \mathrm{C}$ for 10 and $30 \mathrm{~min}$ exhibited a scale growth of $12 \mathrm{~nm}$ and even $50 \mathrm{~nm}$ thickness. This growth, however, was not confirmed by the rest of the samples, and thus was attributed to rupture of the oxide layers during heat-treatment.

The scale growth of the samples, which were reduced by $\mathrm{H}_{2}\left(250^{\circ} \mathrm{C}, 2 \mathrm{~min}\right)$ prior to oxidation are given in Fig. 2-5. To guide the eye, the curves were fitted to a parabolic law. The growth of the scales could be significantly reduced in vacuum. Especially at the higher $\mathrm{O}_{2}$ pressure $(1 \mathrm{~Pa})$ some samples showed erratic scale growth, which was, again, attributed to rupture of the growth-limiting oxide layer. To illustrate the dependence of oxidation on temperature, the values shown in Fig. 2 and 3 are replotted in Fig. 4 and 5 for $p_{\text {total }}=10^{-4} \mathrm{~Pa}$ and $p_{\mathrm{O}_{2}}=1 \mathrm{~Pa}$.

Characterization of the oxide.-The native oxide and the oxide, grown on the molten, metallic solder surface, have been investigated by TEM. For this purpose, a thin carbon layer $(\sim 20 \mathrm{~nm})$ was evaporated onto the samples to improve handling of the very thin oxide films. Then the oxide was extracted from the solder by a selective enchant. Figure 8 shows a TEM micrograph of polycrystalline oxide layer grown at $250^{\circ} \mathrm{C}$ which was identified by single area electron diffraction as consistent with the $\mathrm{SnO}-$ phase. Figure 9 gives the energy dispersive X-ray (EDX) spectrum of the analyzed area. The $\mathrm{Cu}$ in the spectrum stems from the $\mathrm{Cu}$ net, which was used to handle the extracted films.

Extractions of the native oxide layer did not yield in any diffraction pattern. Due to the thinness of the native oxide $(3 \mathrm{~nm})$, it proved impossible to characterize the samples with EDX. The samples were therefore characterized using Mössbauer spectroscopy (MS) (Fig. 10). The native oxide was found to consist of $\mathrm{SnO}_{2}$.

Reduction.-Reduction experiments were carried out in situ, using modified AES equipment. Evaporated and homogenized $\mathrm{SnPb}(60 / 40)$ samples on Pt metallized substrates were introduced into the chamber and heated up to $240^{\circ} \mathrm{C}$. The Pt was covered by the solder from the start and only served as a wetable metallization. Then $\mathrm{H}_{2}$ was in-
EAM 1 in 0 - Dobrevin

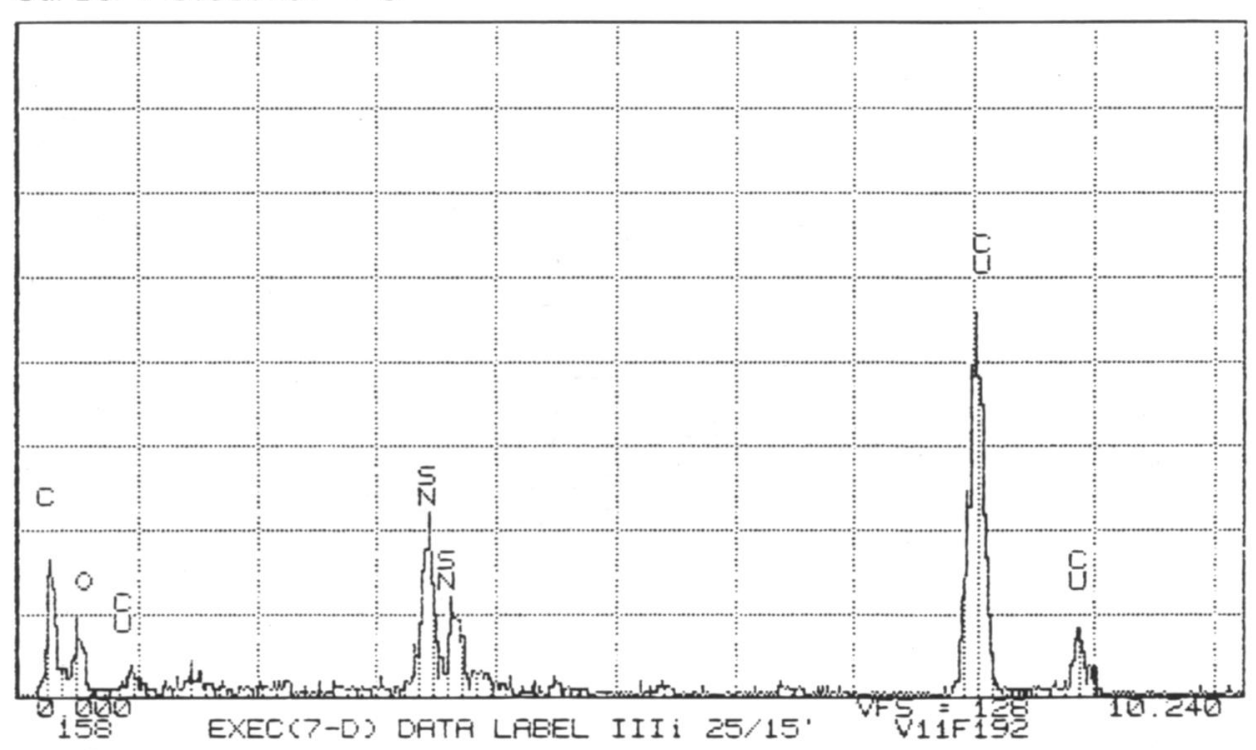

Fig. 9. EDX spectrum of the material, shown in Fig. 8. 


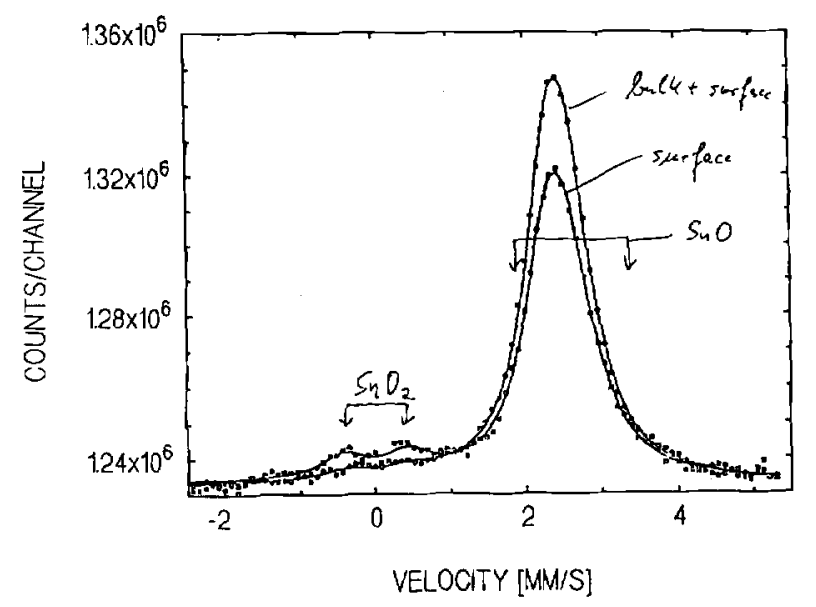

Fig. 10. Mössbauer spectroscopy of the native oxide; only $\mathrm{SnO}_{2}$ could be detected.

jected, leading to a rise of pressure from $10^{-9}$ to $10^{-7} \mathrm{~Pa}$. To monitor the reduction the energy shift of the spectrum from oxidized to metallic tin was chosen. ${ }^{18,23}$ The spectra shown in Fig. 11 were taken during one run. The Sn peak was measured around $430 \mathrm{eV}$. A scale in Fig. 11 is omitted, since the absolute values are dependent on experimental setup and not important if the aim of the measurement is to measure the difference of $\mathrm{Sn}$ in the oxidized and metallic state. Only a short time $(<2 \mathrm{~min})$ after the introduction of $\mathrm{H}_{2}$, the characteristic energy shift of $\sim 4 \mathrm{eV}$ between the Sn oxide and metallic Sn could be observed (Fig. 11).

\section{Conclusion}

This study proves that applying vacuum or lowering the soldering temperatures to, e.g., $200^{\circ} \mathrm{C}$, can significantly decrease the oxide growth on metallic $\mathrm{SnPb}(60 / 40)$.

The native oxide, which has been investigated by MS, consists of $\mathrm{SnO}_{2}$. Electron diffraction of the native oxide films did not yield any patterns. An amorphous structure of the native oxide is most likely. This finding is also in agreement with the literature. ${ }^{12}$ The different growth kinetics of the samples with and without the native oxide as a starting point can therefore be explained by different oxide morphologies; the short-circuit diffusion paths of a crystalline oxide lead to much faster oxide growth, and the samples, covered by the native, presumably amorphous oxide, are much better protected against further oxidation.

Using in situ AES it was demonstrated furthermore, that $\mathrm{H}_{2}$ is able to reduce the oxide on $\mathrm{SnPb}$ solders at typical soldering temperatures (e.g., $240^{\circ} \mathrm{C}$ ). The reduction was measured, using the characteristic energy shift of the Auger spectrum of oxidized and metallic tin of $\sim 4 \mathrm{eV}$. Provided the necessary thermodynamic boundary are met conditions (Table I) the reduction of the $\mathrm{SnO}_{2}$ takes place with no delay. This means, that $\mathrm{H}_{2}$ can be effectively used for soldering applications, which do not allow the use of conventional fluxing agents.

Manuscript submitted June 17, 1997; revised manuscript submitted March 4, 1998.

Mikroelectronik Centret, Denmark Technical University, assisted in meeting the publication costs of this article.

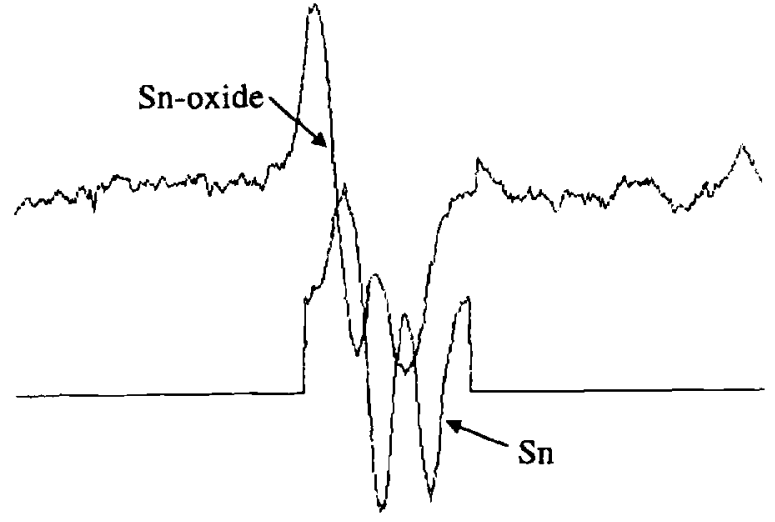

Fig. 11. Energy shift between $\mathrm{Sn}$ oxide and metallic tin, induced by $\mathrm{H}_{2}$ treatment at $240^{\circ} \mathrm{C}$ for $2 \min \left(\mathrm{H}_{2} / \mathrm{H}_{2} \mathrm{O} \geq 100\right)$.

\section{REFERENCES}

1. J. F. Kuhmann, H.-J. Hensel, and H.-G. Bach, in Proceedings of the EuPac ' 96 Conference, DVS, pp. 37-40, (1996).

2. J. F. Kuhmann, H.-J. Hensel, and H.-G. Bach, in Proceedings of the 46th ECTC Conference, CPMT IEEE, pp. 1088-1092 (1996).

3. J. F. Kuhmann and D. Pech, IEEE Photonic Technol. Lett., 8 (1996)

4. Metals Handbook, 9th ed., Vol. 13, Corrosion, ASM International, Metals Park, OH (19xx).

5. R. A. Konetzki, Y. A. Chang, and V. C. Marcotte, J. Mater. Res, 4, 1421 (1989).

6. R. A Konetzki, M. X. Zhang, D. A. Sluzewski, and Y. A. Chang, J. Electron. Pack, 112, 175 (1990).

7. G. Di Giacomo, in Proceedings of the International Symposium on Microelectronics, pp. 322-327 (1986).

8. C. L. Lau and G. K. Wertheim, J. Vac. Sci. Technol., 15, $622(1978)$.

9. R. A. Powell, App. Surf. Sci., 2, 397 (1979).

10. S. C. Britton and K. Bright, Metallurgia, 163 (1957).

11. S. C. Britton and J. C. Sherlock, Br. Corros. J., 9, 96 (1974).

12. W. E. Boggs, P. S. Trozzo, and G. E. Pellissier, J. Electrochem Soc, 108, 13 (1961).

13. R. Kurz and E. Kleiner, Z. Werkstofftech. 2, 8, 418 (1971),

14. E. E. Kluizenaar, J. Vac. Sci. Technol., 1, 1480 (1983).

15. R. G. Miller and C. Q. Bowles, Oxid. Met., 33, 95 (1990)

16. E. Ricci, A. Passerone, and P. Castello, J. Mater. Sci., 29, 1833 (1994).

17. A. Passerone, E. Ricci, and R. Sangiorgi, J. Mater. Sci., 25, 4266 (1990).

18. R. Sangiorgi, C. Senillou, and J. C. Joud, Surf. Sci, 202, 509 (1988).

19. R. D. Deshmukh, M. F. Brady, R. A. Roll, and L. A. King, Int. J. Microcircuits Electron. Packag., 16, 97 (1993).

20. J. H. Lau, Solder Joint Reliability, Theory, and Applications, VanNostrand, Reinhold, New York (1991).

21. J. I. Ivankowits and S. W. Jacobs, SMTCON Technical Proceedings, pp. 283-300, Atlantic City, NJ (1990).

22. W. A. Oates and D. D. Todd, J. Aust. Inst. Met., 7, 109 (1962).

23. A. J. Bevolo, J. D. Verhoeven, and M. Noack, Surf. Sci., 134, 499 (1983).

24. O. Knacke, O. Kubatschewski, and K. Hesselmann, Thermochemical Properties of Inorganic Substances, Springer Verlag, Heidelberg (1991). 